\title{
KONTRIBUSI PENDAPATAN SEKTOR PARIWISATA TERHADAP PENDAPATAN ASLI DAERAH DI PROVINSI DAERAH ISTIMEWA YOGYAKARTA
}

\author{
Mohammad Dendi Abdul Nasir ${ }^{1}$ Nunuk Khomariyah ${ }^{2}$ \\ UIN Sunan Kalijaga Yogyakarta ${ }^{1}$ \\ UIN Sunan Kalijaga Yogyakarta ${ }^{2}$
}

\begin{abstract}
Locally-generated revenue is a regional income from various businesses carried out by the Regional Government to finance regional activities and development. One of the potential sectors is the tourism sector. It is known that during the 2013-2018 tourism sector revenue in the Province of DIY has always increased. According to this matter, it is necessary to analyze several factors that touch the acceptance of the tourism sector in DIY Province. This study aims to analyze the influence of the variable the number of tourists, the number of hotels, and the number of tourism objects to Locally-generated Revenue in the Province of DIY. The data of this research are secondary data. The analytical tool used in this study is panel data. Partially, the number of tourists and the number of hotels have a significant influence, while the number of tourist objects has no effect on the locally-generated revenue from the tourism sector.
\end{abstract}

Keywords: Locally-Generated Revenue, Tourism, Number of Tourists, Number of Hotels, Number of Tourism Objects.

\section{LATAR BELAKANG}

Pemerintah pusat maupun pemerintah daerah mempunyai kendali untuk melakukan pembangunan ekonomi, oleh karena itu pemerintah pusat memberikan otoritas penuh kepada pemerintah daerah untuk mengelola kepentingan masyarakat sesuai dengan potensi daerah tersebut, hal itu mengacu pada Undang-undang Nomor 23 Tahun 2014 tentang Pemerintahan Daerah.

Pemberian otoritas tersebut termasuk juga didalamnya otoritas dalam mencari sumber pembiayaan dalam pelaksaan kepemerintahan daerah. Salah satu sumber pembiayaan dapat diperoleh dari Pendapatan Asli Daerah (Jessy: 2014). Oleh karenanya, pemerintah daerah diharapkan bisa memberikan kontribusi nyata dalam rangka meningkatkan Pendapatan Asli Daerah (PAD). Salah satu upaya tersebut adalah dengan memaksimalkan potensi daerah pada sektor pariwisata.

Undang-Undang Nomor 10 tahun 2009 Tentang Kepariwisataan menjelaskan bahwa pariwisata mempunyai tujuan untuk meningkatkan pendapatan nasional, memperluas lapangan kerja, mendorong pembangunan daerah, memperkenalkan obyek wisata di Indonesia, memupuk rasa cinta tanah air, memperkuat kesatuan bangsa serta mempererat hubungan persahabatan antar bangsa.

Provinsi Daerah Istimewa Yogyakarta (DIY) adalah salah satu Provinsi yang ada di Indonesia yang memiliki potensi pariwisata, dimana potensi tersebut menjadi sektor utama yang memberi sumbangsih dalam peningkatan Pendapatan Asli Daerah. Banyaknya obyek wisata, akses yang mudah serta kenyamanan menjadi daya tarik tersendiri bagi wisatawan untuk datang ke Yogyakarta (Bappeda DIY: 2018).

Tabel 1. Jumlah PAD Sektor Pariwisata, Jumlah Wisawatan, Jumlah Hotel, Jumlah Obyek Wisata Prov DIY

\begin{tabular}{|c|c|c|c|c|c|}
\hline No. & Tahun & $\begin{array}{c}\text { PAD DIY Sektor } \\
\text { Pariwisata }\end{array}$ & $\begin{array}{c}\text { Jumlah } \\
\text { Wisatawan }\end{array}$ & $\begin{array}{c}\text { Jumlah } \\
\text { Hotel }\end{array}$ & $\begin{array}{c}\text { Jumlah } \\
\text { Obyek } \\
\text { Wisata }\end{array}$ \\
\hline 1. & 2013 & $\operatorname{Rp~} 188.821 .138 .834$ & 11.960 .325 & 1170 & 132 \\
\hline 2. & 2014 & $\operatorname{Rp} 236.932 .548 .770$ & 14.163 .910 & 1138 & 132 \\
\hline 3. & 2015 & $\operatorname{Rp} 266.941 .954 .875$ & 19.226 .220 & 1166 & 176 \\
\hline
\end{tabular}


MOHAMMAD DENDI ABDUL NASIR ${ }^{1}$, NUNUK KHOMARIYAH ${ }^{2}$

Kontribusi Pendapatan Sektor Pariwisata Terhadap Pendapatan Asli Daerah Di Provinsi Daerah Istimewa Yogyakarta

\begin{tabular}{|c|c|c|c|c|c|}
\hline 4. & 2016 & Rp 353.823.527.820 & 21.710 .756 & 1165 & 149 \\
\hline 5. & 2017 & RP 423.014.287.594 & 25.950 .795 & 1179 & 186 \\
\hline 6. & 2018 & Rp 475.224.370.046 & 26.515 .788 & 1618 & 186 \\
\hline
\end{tabular}

Sumber: BPS Provinsi Yogyakarta

Tabel diatas menjelaskan bahwa Pendapatan Asli Daerah dan jumlah wisatawan Provinsi Daerah Istimewa Yogyakarta dari tahun 2013 sampai tahun 2018 selalu mengalami peningkatan. Sedangkan jumlah hotel dan jumlah obyek wisata mengalami fluktuasi. Dengan meningkatnya Pendapatan Asli Daerah, menunjukkan bahwa Provinsi Daerah Istimewa Yogyakarta selalu memaksimalkan potensi-potensi yang ada pada sektor pariwisata. Sedangkan meningkatnya jumlah wisatawan menjadikan permintaan pasar juga meningkat dikarenakan belanja wisawatan. Oleh karena itu, upaya untuk memenuhi permintaan tersebut diperlukan berbagai tindakan inovatif dan juga investasi di berbagai sektor seperti akomodasi perhotelan, transportasi publik, dan juga industri rumah makan (Spillane: 1994).

Beberapa penelitian terdahulu yang menyinggung peran sektor pariwisata terhadap pendapatan asli daerah pernah dilakukan beberapa peneliti, diantaranya penelitian yang dilakukan oleh Widiyanti (2017) yang berjudul analisis pengaruh jumlah obyek wisata, PDRB, jumlah hotel, jumlah restoran dan rumah makan terhadap pendapatan asli daerah sektor pariwisata di DIY Tahun 2010-2015. Hasil penelitian menunjukkan bahwa hanya variabel jumlah obyek wisata yang tidak mempunyai pengaruh terhadap PAD, sedangkan variabel lainnya seperti PDRB, jumlah hotel, dan jumlah restoran mempunyai pengaruh positif dan signifikan terhadap PAD. Kemudian penelitian yang dilakukan oleh Devinawati (2011) yang meneliti tentang strategi yang dilakukan pemerintah Kabupaten Kerinci dalam mengoptimalkan sektor pariwisata untuk meningkatkan PAD. Hasil penelitian tersebut menunjukkan bahwa Kabupaten Kerinci belum bisa memberi sumbangan yang optimal terhadap PAD dalam hal pengembangan pariwisata, karena sektor pariwisata belum bisa memberikan sumbangsih yang besar terhadap PAD.

\section{KAJIAN LITERATUR}

\section{Sektor Pariwisata}

Menurut UU RI No.10 tahun 2009

pariwisata adalalah berbagai kegiatan perjalan yag dilakukan oleh seseorang atau sekelompok orang yang mengunjungi suatu tempat dengan tujuan tertentu yang didukung oleh berbagai fasilitas yang disediakan oleh pemerintah, pengusaha, pemerintah daerah bahkan masyarakat sekitarnya sedangkan kepariwisataan adalah keseluruhan kegiatan yang terkait dengan pariwisata dan bersifat multidimensi serta multidisiplin yang muncul sebagai wujud kbutuhan serang dan negara serta interaksi antara wisatawan dengan masyarakat sekitarnya, sesama wistawan, pemerintah, pemerintah daerah dan pengusaha wisata. Selain itu pada Bab II pasal 3 kepariwisataan berfungsi memenuhi kebutuhan jasmani, rohani dan intelektual setiap wisatawaan yang berkunjung dengan rekreasi dan perjalanan serta meningkatkan pendapatan negara untuk mewujudkan kesejahteraan rakyat.

Daerah istimewa Yogyakarta yang relatif aman dan nyaman dengan keramahtamahan warganya menjadikan kota ini banyak diminati wisatawan untuk berkunjung, jadi tidak mengherankan jika jumlah wisatawan mancanegara ataupun wisatawan nusantara setiap tahunnya mengalami peningkatan hal itu juga disebabkan oleh bertambahnya jumlah obyek wisata. Arahan pembangunan kepariwisataan DIY hinnga saat ini semakain jelas dengan mengacu kepada Perda DIY No. 1 tahun 2012 tentang Rencana Induk Pembangunan Kepariwisataan (RIPARDA) DIY, yang telah dijadikan sumber utama untuk memandu arah pengembangan kepariwisataan DIY yang berwaawasan budaya. Perda telah memberikan rambu - rambu yang harus dipatuhi oleh seluruh tempat kepariwisataan DIY guna untuk mencapai visi pembangunan kepariwisataan yang telah ditetapkan. 


\section{Pendapatan Asli Daerah (PAD)}

Pendapatan merupakan sebuah aliran penerimaan harta lain yang diterima dari konsumen atas hasil penjualan barang atau pemberian jasa (Yusuf: 2001). Sedangkan Pendapatan Asli Daerah adalah penerimaan yang diperoleh dari sumber - sumber dalam wilayah itu sendiri yang dipungut berdasarkan peraturan daerah sesuai dengan peraturan yang tertera pada undang - undang (Yani: 2002).

Menurut UU No. 33 tahun 2004 Bab II pasal 3 PAD bertujuan memberikan kewenangan kepada pemerintah daerah untuk mendanai pelaksanaan otonomi daerah sesuai dengan potensi sebuah daerah sebagai perwujudan Desentralisasi. Selain itu pada Bab V pasal 6 Pendapatan Asli daerah berasal dari pajak daerah, Retribusi Daerah, hasil pengelolaan kekayaan Daerah yang dipisahkan, dan lain - lain PAD yang sah diantaranya meliputi hasil penjualan kekayaan daerah yang tidak dipisahkan, jasa giro, pendapatan bunga, keuntungan selisih nilai tukar rupiah terhadap mata uang asing dan komis, potongan ataupun dalam bentuk lain yang sebagai akibat dari penjualan atau pengadaan barang dan jasa yang dilakukan oleh daerah.

\footnotetext{
KERANGKA PEMIKIRAN

Penelitian ini bertujuan untuk menganalisis pengaruh sektor pariwisata terhadap pendapatan asli daerah provinsi Daerah Istimewa Yogyakarta tahun 20132018. Dimana variabel independen meliputi Jumlah Wisatawan, Jumlah Hotel, dan Jumlah Obyek Wisata. Sedangkan Pendapatan Asli Daerah Sektor Pariwisata menjadi variabel dependen. Sehingga diharapkan penelitian ini dapat membantu dalam mengambil solusi maupun kebijakan untuk meningkatkan pendapatan daerah dari sektor pariwisata di Provinsi Daerah Istimewa Yogyakarta pada masa yang akan datang.
}

\section{Gambar 1. Kerangka Pemikiran}

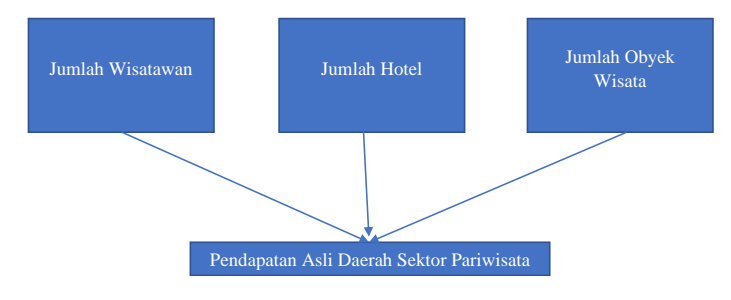

\section{HIPOTESIS}

Berdasarkan permasalahan penelitian ini, maka uji hipotesis dalam penelitian ini adalah antara lain:

1. Variabel Jumlah Wisatawan diduga memiliki hubungan positif terhadap Pendapatan Asli Daerah Sektor Pariwisata di Daerah Istimewa Yogyakarta.

2. Variabel Jumlah Hotel diduga memiliki hubungan positif terhadap Pendapatan Asli Daerah Sektor Pariwisata di Daerah Istimewa Yogyakarta.

3. Variabel Jumlah Obyek Wisata diduga memiliki hubungan positif terhadap Pendapatan Asli Daerah Sektor Pariwisata di Daerah Istimewa Yogyakarta.

\section{METODOLOGI PENELITIAN}

Penelitian ini adalah penelitian dengan menggunakan metode kuantitatif. Dalam mengestimasi data penelitian, peneliti menggunakan data sekunder yang bersumber dari Badan Pusat Statistika (BPS) Provinsi Yogyakarta dan Dinas Pariwisata Provinsi Yogyakarta. Jenis data yang digunakan adalah metode data panel, yaitu menggabungkan antara data time series dan cross section. Data time series yang digunakan adalah data tahunan dimulai dari tahun 2013 sampai tahun 2018 dan data cross section sebanyak 5 Kabupaten/Kota yang ada di Provinsi Daerah Istimewa Yogyakarta, diantaranya Kabupaten Kulon Progo, Kabupaten Bantul, Kabupaten Gunung Kidul, Kabupaten Sleman, dan Kota Yogyakarta.

Pada uji hipotesis menolak atau gagal menolaknya Ho tergantung dengan $\alpha$ alfa yang digunakan, semakin kecil $\alpha$ akan semakin kecil probabilitas menolak hipotesis yang benar dan semakin besar $\alpha$ akan 
MOHAMMAD DENDI ABDUL NASIR ${ }^{1}$, NUNUK KHOMARIYAH ${ }^{2}$

Kontribusi Pendapatan Sektor Pariwisata Terhadap Pendapatan Asli Daerah Di Provinsi Daerah Istimewa Yogyakarta

semakin besar pula menolak hipotesis yang benar. Dalam praktik $\alpha$ ditentukan secara arbiter yaitu $1 \% \quad 5 \%$ dan $10 \%$. Jika nilai probabilitas $<$ dari nilai $\alpha$ yang dipilih maka menolak Ho atau menerima $\mathrm{Ha}$ dan sebaliknya jika nilai probabilitas > dari nilai a yang dipilih maka Gagal Menolak Ho (Widarjono: 2018).

Untuk mengetahui besarnya pengaruh dari variabel independen terhadap variabel dependen secara parsial maupun simultan, maka penelitian ini menggunakan teknik analisis regresi linier berganda data panel dengan metode Panel Least Squares (PLS). Data diolah menggunakan software Eviews 10. berikut:

Adapun formulasinya adalah sebagai $\ln \mathrm{Y}_{\mathrm{it}}=\beta_{0}+\beta_{1} \ln \mathrm{X}_{1 \mathrm{it}}+\beta_{2} \ln \mathrm{X}_{2 \mathrm{it}}+\beta_{3} \ln \mathrm{X}_{3 \mathrm{it}}+\mathrm{e}_{\mathrm{it}}$ Dimana:

$$
\begin{array}{ll}
\ln & =\text { Logaritma Natural } \\
\mathrm{Y} & =\text { Pendapatan Asli Daerah } \\
\mathrm{X}_{1} & =\text { Jumlah Wisatawan } \\
\mathrm{X}_{2} & =\text { Jumlah Hotel } \\
\mathrm{X}_{3} & =\text { Jumlah Obyek Wisata } \\
\beta_{0,}, \beta_{1}, \beta_{2}, \beta_{3} & =\text { Koefisien Regresi } \\
\mathrm{i} & =\text { Kab/kota di DIY } \\
\mathrm{t} & =\text { Waktu (tahun 2013-2018) } \\
\mathrm{e} & =\text { Standar Error }
\end{array}
$$

\section{DEFINISI OPERASIONAL VARIABEL}

1. Variabel Dependen (Y)

Variabel dependen yang digunakan dalam penelitian yaitu Pendapatan Asli Daerah (PAD) Sektor Pariwisata Provinsi Daerah Istimewa Yogyakarta pada masingmasing kabupaten/kota. Data ini diperoleh dari Buku Statistik Kepariwisataan Dinas Pariwisata DIY dan Daerah Istimewa Yogyakarta Dalam Angka yang dikeluarkan oleh Badan Pusat Statistika DIY. Data yang diambil berdasarkan tahun 2013-2018 dan dalam satuan juta rupiah.

2. Variabel Independen (X)

a. Jumlah Wisatawan $\left(\mathrm{X}_{1}\right)$

Data jumlah wisatawan yang digunakan merupakan penggabungan antara data jumlah wisatawan mancanegara dan wisatawan nusantara pada masing-masing Kabupaten/Kota menurut Daya Tarik Wisata di DIY. Data ini diperoleh dari Buku Statistik Kepariwisataan Dinas Pariwisata DIY dan Daerah Istimewa Yogyakarta Dalam Angka yang dikeluarkan oleh Badan Pusat Statistika DIY. Data yang diambil berdasarkan tahun 2013-2018 dan dalam satuan orang.

b. Jumlah Hotel $\left(\mathrm{X}_{2}\right)$

c. Data jumlah hotel merupakan penggabungan antara data jumlah hotel bintang dan non bintang pada masing-masing Kabupaten/Kota di DIY. Data ini diperoleh dari Buku Statistik Kepariwisataan Dinas Pariwisata DIY dan Daerah Istimewa Yogyakarta Dalam Angka yang dikeluarkan oleh Badan Pusat Statistika DIY. Data yang diambil berdasarkan tahun 2013-2018 dan dalam satuan unit.

d. Jumlah Obyek Wisata $\left(\mathrm{X}_{3}\right)$

e. Data ini meliputi semua tempat wisata yang diperoleh dari Buku Statistik Kepariwisataan Dinas Pariwisata DIY dan Daerah Istimewa Yogyakarta Dalam Angka yang dikeluarkan oleh Badan Pusat Statistika DIY. Data yang diambil berdasarkan tahun 2013-2018 dan dalam satuan unit.

\section{HASIL ANALISIS DAN PEMBAHASAN}

Berdasarkan hasil pengujian analisis menggunakan Uji Chow, Uji Hausman, dan Uji Breusch-pagan, ketiganya menunjukkan hasil pemilihan uji terbaik menggunakan model Fixed Effect, sebagai berikut:

Tabel 2. Hasil Analisis Model Fixed Effect

\begin{tabular}{|l|l|l|l|}
\hline No & Variabel & Koefisien & Probabilitas \\
\hline 1 & Jumlah Wisatawan & 0.496100 & 0.0002 \\
\hline 2 & Jumlah Hotel & 0.616415 & 0.0994 \\
\hline 3 & $\begin{array}{l}\text { Jumlah Obyek } \\
\text { Wisata }\end{array}$ & 0.004626 & 0.9734 \\
\hline \multicolumn{3}{|c|}{ R-squared=0.966899 } \\
\hline
\end{tabular}

Sumber: Hasil diolah dari Eviews 10 
Berdasarkan tabel 2, setiap variabel independen memberikan pengaruh yang berbeda-beda terhadap variabel dependen. Estimasi data panel dengan model Fixed Effect diperoleh hasil sebagai berikut:

a) Pengaruh Jumlah Wisatawan terhadap Pendapatan Asli Daerah Sektor Pariwisata di Kabupaten/Kota Provinsi Daerah Istimewa Yogyakarta

Berdasarkan hasil pengolahan data penelitian, variabel Jumlah Wisatawan memiliki koefisien sebesar 0.496100 dan probabilitas sebesar 0.0002 maka Menolak Ho pada $\alpha 5 \%$, yang berarti bahwa variabel Jumlah Wisatawan memiliki pengaruh yang positif dan signifikan terhadap Pendapatan Asli Daerah Sektor Pariwisata di Kabupaten/Kota Provinsi Daerah Istimewa Yogyakarta. Dengan koefisien regresi sebesar 0.496100 yang artinya bahwa setiap jumlah wisatawan naik 1 persen, maka Pendapatan Asli Daerah Sektor Pariwisata di Kabupaten/Kota Provinsi Daerah Istimewa Yogyakarta akan mengalami kenaikan sebesar 0.496100 persen.

Hasil ini sesuai dengan hipotesis penelitian yang menyatakan bahwa jumlah wisatawan berpengaruh positif dan signifikan terhadap pendapatan asli daerah sektor pariwisata di kabupaten/kota provinsi Daerah Istimewa Yogyakarta 2013-2018. Hasil penelitian ini sejalan dengan penelitian sebelumnya yang dilakukan oleh Ulfa (2019) dimana penelitian tersebut menunjukkan variabel jumlah wisatawan berpengaruh positif dan signifikan terhadap pendapatan asli daerah sektor pariwisata di Kabupaten/Kota Provinsi Daerah Istimewa Yogyakarta. Semakin banyaknya jumlah wisatawan yang berkunjung ke Daerah Istimewa Yogyakarta maka akan semakin tinggi pula Pendapatan Asli Daerah Sektor Pariwisata yang didapat

Berpengaruhnya jumlah wisatawan terhadap pendapatan asli daerah berasal dari pembayaran tiket masuk wisata, pembelian makanan ataupun minuman, dan juga cinderamata lainnya. Hal ini membuat usaha-usaha kecil yang terdapat disekitar tempat wisata menjadi hidup dan berkembamg dengan baik sehingga dapat meningkatkan pendapatan asli daerah sektor pariwisata di Kabupaten/Kota Provinsi Daerah Istimewa Yogyakarta. Provinsi ini juga terkenal dengan sebutan sejuta wisata yang hingga saat ini menjadi daerah tujuan wisata yang terkenal di Indonesia bahkan mancanegara.

b) Pengaruh Jumlah Hotel terhadap Pendapatan Asli Daerah Sektor Pariwisata di Kabupaten/Kota Provinsi Daerah Istimewa Yogyakarta

Berdasarkan hasil pengolahan data penelitian, variabel Jumlah Hotel memiliki koefisien sebesar 0.616415 dan probabilitas sebesar 0.0994 menolak Ho pada $\alpha 10 \%$, yang berarti bahwa variabel Jumlah Wisatawan memiliki pengaruh yang positif dan signifikan terhadap Pendapatan Asli Daerah Sektor Pariwisata di Kabupaten/Kota Provinsi Daerah Istimewa Yogyakarta. Dengan koefisien regresi sebesar 0.616415 yang artinya bahwa setiap jumlah hotel naik 1 persen, maka Pendapatan Asli Daerah Sektor Pariwisata di Kabupaten/Kota Provinsi Daerah Istimewa Yogyakarta akan mengalami kenaikan sebesar 0.616415 persen.

Hasil ini menjawab hipotesis penelitian, bahwa Jumlah Hotel berpengaruh positif dan signifikan terhadap pendapatan asli daerah sektor pariwisata di kabupaten/kota Provinsi Daerah Istimewa Yogyakarta 2013-2018. Hasil penelitian ini sama seperti penelitian sebelumnya yang dilakukan oleh Rozikin (2016) hasil penelitian tersebut menunjukkan bahwa variabel Jumlah Hotel berpengaruh positif dan signifikan terhadap pendapatan asli daerah sektor pariwisata. Hasil tersebut menunjukkan bahwa sektor pariwisata dapat meningkatkan pendapatan. Adanya hotel menjadi salah satu pendapatan pemilik hotel maupun pemerintah daerah. 
MOHAMMAD DENDI ABDUL NASIR ${ }^{1}$, NUNUK KHOMARIYAH ${ }^{2}$

Kontribusi Pendapatan Sektor Pariwisata Terhadap Pendapatan Asli Daerah Di Provinsi Daerah Istimewa Yogyakarta

c) Pengaruh Jumlah Obyek Wisata terhadap Pendapatan Asli Daerah Sektor Pariwisata di Kabupaten/Kota Provinsi Daerah Istimewa Yogyakarta

Hasil analisis menunjukkan bahwa Jumlah Obyek Wisata memiliki probabilitas sebesar 0.9509 dan koefisien regresi sebesar 0.017846 Gagal Menolak Ho pada $\alpha 10 \%$ yang dapat diartikan bahwa dalam penelitian ini variabel Jumlah Obyek Wisata berpengaruh positif dan tidak signifikan terhadap Pendapatan Asli Daerah Sektor Pariwisata di Kabupaten/Kota Provinsi Daerah Istimewa Yogyakarta.

Hasil menjawab hipotesis penelitian, bahwa jumlah obyek wisata tidak berpengaruh berpengaruh positif dan tidak signifikan terhadap pendapatan asli daerah sektor pariwisata di Kabupaten/Kota Provinsi Daerah Istimewa Yogyakarta 2013-2018. Hasil penelitian ini sama seperti penelitian sebelumnya yang dilakukan oleh Huda (2009) hasil penelitian tersebut menyatakan variabel jumlah obyek wisata tidak berpengaruh dan tidak signifikan terhadap pendapatan asli daerah sektor pariwisata di Kabupaten/Kota Provinsi Daerah Istimewa Yogyakarta.

Hal ini bisa disebabkan karena akses yang belum memadai menuju obyek wisata yang baru diresmikan. Dengan demikian, seluruh akses menuju obyek wisata harus memadai, sehingga kunjungan wisatawan merata ke semua obyek wisata yang ada di Provinsi Daerah Istimewa Yogyakarta.

d) Koefisien Determinasi

Dari hasil uji variabel Jumlah Wisatawan, Jumlah Hotel dan Jumlah Obyek Wisata terhadap Pendapatan Asli Daerah Sektor Pariwisata di Kabupaten/Kota Provinsi Daerah Istimewa Yogyakarta tahun 2013-2018 diperoleh niai $\mathrm{R}^{2}$ sebesar 0.966899, yang berarti bahwa pendapatan asli daerah sektor pariwisata di Kabupaten/Kota Provinsi Daerah Istimewa Yogyakarta dipengaruhi sebesar 96,7\% dipengaruhi oleh Jumlah Wisatawan, Jumlah Hotel dan Jumlah Obyek Wisata sedangkan sisanya sebesar 3,3\% dipengaruhi oleh variabel diluar variabel penelitian ini.

e) Perbedaan Intersep antar Kabupaten/Kota

Tabel 3. Perbedaan Intersep antar

Kabupaten/Kota

\begin{tabular}{|l|c|}
\hline \multicolumn{1}{|c|}{ CROSSID } & Effect \\
\hline Kulon Progo & -0.591300 \\
\hline Bantul & -0.725735 \\
\hline Gunung Kidul & 0.168755 \\
\hline Sleman & 0.503433 \\
\hline Kota & 0.644847 \\
\hline \multicolumn{2}{|l|}{ Sumber: Hasil diolah dari Eviews 10}
\end{tabular}

Sumber: Hasil diolah dari Eviews 10

Dari Tabel 3, dapat dilihat bahwa nilai intersep Kota Yogyakarta lebih tinggi daripada Kabupaten yang lain. Hal ini menunjukkan bahwa Kota Yogyakarta menyumbang Pendapatan Asli Daerah Provinsi Daerah Istimewa Yogyakarta lebih banyak daripada Kabupaten lain.

Hal ini disebabkan karena obyek wisata di Kota Yogyakarta lebih banyak dikunjungi wisatawan, seperti Tugu Yogyakarta, Alunalun Kidul, Titik Nol Kilometer, Keraton Yogyakarta, Pemandian Tamansari, Musium Batik, Taman Pintar, Malioboro, Benteng Vredeburg, serta masih banyak lagi.

\section{KESIMPULAN}

Berdasarkan analisis dan pembahasan yang telah dilakukan dapat diambil kesimpulan sebagai berikut:

I. Variabel Jumlah Wisatawan berpengaruh positif dan signifikan terhadap Pendapatan Asli Daerah Sektor Pariwisata di DIY yang berarti jika jumlah wisatawan semakin meningkat, maka Pendapatan Asli Daerah Sektor Pariwisata di Provinsi Daerah Istimewa Yogyakarta juga akan meningkat.

II. Variabel Jumlah Hotel berpengaruh positif dan signifikan terhadap Pendapatan Asli Daerah Sektor Pariwisata di DIY yang berarti jika jumlah hotel semakin bertambah, maka Pendapatan Asli Daerah Sektor Pariwisata di Provinsi Daerah Istimewa Yogyakarta juga akan meningkat.

III. Variabel Jumlah Obyek Wisata tidak berpengaruh terhadap Pendapatan Asli 
Daerah Sektor Pariwisata di DIYyang berarti ketika jumlah obyek wisata bertambah, maka tidak diikuti dengan peningkatan Pendapatan Asli Daerah Sektor Pariwisata di Provinsi Daerah Istimewa Yogyakarta.

\begin{tabular}{crr}
\hline \multicolumn{3}{c}{ REFERENSI } \\
\hline Bappeda DIY. $\quad(2018)$. & Arahan \\
Pengembangan & Kawasan & Pariwisata \\
DIY. Publikasi Umum &
\end{tabular}

Dinas Pariwisata DIY. (2013). Statistk kepariwisataan.

Dinas Pariwisata DIY. (2014). Statistk kepariwisataan.

Dinas Pariwisata DIY. (2015). Statistk kepariwisataan.

Dinas Pariwisata DIY. (2016). Statistk kepariwisataan.

Dinas Pariwisata DIY. (2017). Statistk kepariwisataan.

Dinas Pariwisata DIY. (2018). Statistk kepariwisataan.

Devinawati, L. (2011). Strategi Optimalisasi Aset Daerah di Sektor Pariwisata Kabupaten Kerinci dalam Meningkatkan Pendapatan Asli Daerah (PAD). Skripsi. Padang: Universitas Andalas

Huda, S. (2009). Analisis Penerimaan Devisa Sektor Pariwisata dan Faktor-Faktor Yang Mempengaruhi di Provinsi Jawa Timur. Jurnal Aplikasi Manajemen, Vol. 7 No. 1

Jessy, Tiara Apriani Putri. (2014). Strategi Peningkatan Pendapatan Asli Daerah (PAD) Kota Balikpapan Melalui Pajak Daerah Sektor Pariwisata. Journal Administrasi Negara, Vol. 5 No. 3

Rozikin, K. M. (2016). Pengaruh Jumlah Kunjungan Wisatawan Dan Jumlah Hotel Terhadap Pendapatan Asli Daerah Di Pulau Lombok. Skripsi. Yogyakarta: Universitas Muhammadiyah Yogyakarta

Spillane, James J. (1994). Pariwisata Indonesia Siasat Ekonomi dan Rekayasa Kebudayaan. Yogyakarta: Kanisius

Ulfa, Farah Fadillah. (2019). Pengaruh Sektor Pariwisata Terhadap
Pendapatan Asli Daerah Sektor Pariwisata Di Daerah Istimewa Yogyakarta. Skripsi. Yogyakarta: Universitas Muhammadiyah Yogyakarta

Undang-Undang Nomor 23 Tahun 2014 Undang-Undang Nomor 10 Tahun 2009 Undang-Undang Nomor 33 Tahun 2004 Widarjono, Agus. (2018). Ekonometrik Pengantar dan Aplikasinya Edisi-5. Yogyakarta: UPP STIM YKPN

Widiyanti, Naning. (2017). Analisis Pengaruh Jumlah Obyek Wisata, PDRB, Jumlah Hotel, Jumlah Restoran dan Rumah Makan Terhadap Pendapatan Asli Daerah Sektor Pariwisata di DIY Tahun 2010-2015. Skripsi. Yogyakarta: Universitas Muhammadiyah Yogyakarta

Yani, Ahmad. (2002). Hubungan Keuangan Antara Pemerintah Pusat dan Daerah di Indonesia. Jakarta: PT. Rajagrafindo

Yusuf, Haryono. (2001). Dasar - Dasar Akuntansi, Edisi Ke-5. Yogyakarta: Bagian Penerbit STIE YPKN

Yogyakarta Dalam Angka 2013.

Yogyakarta Dalam Angka 2014.

Yogyakarta Dalam Angka 2015.

Yogyakarta Dalam Angka 2016

Yogyakarta Dalam Angka 2017

Yogyakarta Dalam Angka 2018 